\title{
Influence of ethnocentrism on consumer preference patterns: the case of olive oil in Portugal
}

\author{
Rodolfo Bernabéu*, Fátima Oliveira**, Adrián Rabadán*, \\ Mónica Díaz ${ }^{\star \star *}$
}

DOI: $10.30682 / \mathrm{nm} 2001 \mathrm{~d}$

JEL codes: M31, Q11, Q19

\begin{abstract}
Consumers are influenced by a multitude of stimuli, which affect their behaviour and guide their preferences towards a particular product. Ethnocentric tendencies are one of these stimuli, understood as consumers' positive attitudes towards goods produced in their own region rather than those from other regions. From this perspective, the current study describes ethnocentric tendencies and identifies olive oil consumer preferences from Lisbon (Portugal). CETSCALE and the conjoint analysis technique have been used for this purpose. Results show that Portuguese olive oil consumers exhibit a strong ethnocentric tendency but the price attribute is also key. Nonetheless, there exists a less ethnocentric segment, on which foreign business strategy can be focused. On this segment, consumers attach lower relative importance to the price and higher relative importance to differentiated-quality parameters: oil type (extra virgin), bottle (glass) and production system (organic).
\end{abstract}

Keywords: Consumer behaviour, Consumer Ethnocentric Tendency Scale (CETSCALE), Conjoint Analysis, organic olive oil, extra virgin olive oil.

\section{Introduction}

Given their agro-climatic conditions, the countries around the Mediterranean basin form the centre of world olive oil production, accounting for three-quarters of global olive oil production. The mean olive oil production from 2001 to 2014 was $2,830,000$ t, of which $42 \%$ corresponded to Spain, $19 \%$ to Italy, and 12\% to Greece, these three countries being the main producers. The Mediterranean olive oil produc- ing countries account for $75 \%$ of consumption. The main producers, Italy, Spain and Greece, consume $25.4 \%, 19.9 \%$ and $8.7 \%$ respectively. Per capita consumption is $15.5 \mathrm{~kg} /$ year in Greece, $11.4 \mathrm{~kg} /$ year in Spain, $10.3 \mathrm{~kg} /$ year in Italy and $7.1 \mathrm{~kg} /$ year in Portugal (IOC, 2015).

However, olive oil consumption is not only limited to this production area. There is a growing worldwide trend associated with the benefits of the Mediterranean diet, of which olive oil is an essential part.

\footnotetext{
* Escuela Técnica Superior de Ingenieros Agrónomos y de Montes, Universidad de Castilla-La Mancha, Albacete, Spain.

${ }^{* *}$ Escola Superior Agrária de Coimbra, Instituto Politécnico de Coimbra, Coimbra, Portugal.

*** Escuela de Ingenieros Agrónomos, Universidad de Castilla-La Mancha, Ciudad Real, Spain.

Corresponding author: Rodolfo.Bernabeu@uclm.es
} 
In this regard, the consumption of olive oil is associated with the prevention of cardiovascular diseases (the fatty acids found in virgin olive oil, especially oleic acid, help to reduce LDL cholesterol levels, while enhancing HDL levels, favours arterial vasodilation, improves blood circulation and lowers blood pressure) (Hernáez et al., 2016; Sikand et al., 2015). Olive oil also facilitates the digestive function (Alarcón de la Lastra et al., 2001), helps to combat constipation (Ramos et al., 2015), reduces complications in type II diabetes mellitus patients (Sikand et al., 2015; Esposito et al., 2017), contributes to the correct mineralisation and development of the bones, protects against cellular oxidative stress and increases longevity by reducing the number of deaths from cardiovascular disease and certain types of cancer (Ostrowska et al., 2006; Chin and Ima-Nirwana, 2016; Del Río et al., 2016).

Focusing on the Portugal case, mean production of olive oil in this country from 2001 to 2014 was $48,500 \mathrm{t}$, while mean consumption was 74,000 t (IOC, 2015). In 2015, Portugal imported 103,260 t of olive oil, been Spain the main exporter $(76,486 \mathrm{t})$, followed at a considerable distance by Tunisia (5,794 t) and Morocco $(1,115$ t) (COMTRADE, 2015). Per capita consumption of olive oil is $38 \%$ lower in Portugal than in Spain, which represents an opportunity not only for local producers, but also for olive oil producers from other culturally similar countries, given the previously mentioned health benefits of the Mediterranean diets.

From a marketing perspective, consumers are the key factor when designing business strategies. It is also clearly a risk to design these strategies without knowledge of consumer behaviour. Thus, if olive oil producers wish to generate and exploit all business opportunities, it is necessary to closely analyse consumer behaviour.

Consumers are influenced by a multitude of stimuli, which affect their behaviour and guide their preferences towards a particular product. Ethnocentric tendencies are one of these stimuli, understood as consumers' positive attitudes towards goods produced in their geographical area of origin. Pragmatically speaking, we can say that ethnocentrism is the name given to the sense of belonging felt by any individual. More importantly, it explains the reason why a group accepts certain choices rather than others, which, in the case that concerns us here, refers to accepting certain buying behaviours rather than others (Witkowsky, 1998).

The term consumer ethnocentrism was first used to explain the preference or rejection of consumers towards products from other countries, but this concept has currently been extended to include products produced in different regions of the same country (Bernabéu et al., 2013). In this regard, less ethnocentric consumers are able to choose products regardless of their origin, since they evaluate them by taking into account all their qualities and may even prefer products from other regions to those of their own.

By contrast, more ethnocentric consumers may feel that products from other regions act against their regional identity, damage the local economy and cause the loss of jobs (Bilkey and Nes, 1982; Chasin et al., 1988; Durvasula et al., 1997; Han, 1988; Hung, 1989; Johansson et al., 1985; Kaynak and Kara, 1996; Sharma et al., 1995; Supphellen and Gronhaug, 2003; Wall and Heslop, 1986; White, 1979). While this feeling is persistent and may resurface strongly in times of economic crisis, it may give rise to morally wrong opinions (Shimp and Sharma, 1987).

In light of the above, it is of interest to be able to measure the degree of consumers' ethnocentrism to determine the possibilities for commercial success of products in the market of destination, olive oil in our case. The final aim of this work is to propose business strategies to increase olive oil consumption in Portugal. To determine the existence of market opportunities, we will first analyse consumers and classify them according to their degree of ethnocentrism. Second, we will determine their preferences regarding olive oil, and, finally, we will establish the business strategies required for companies wishing to enter, position and differentiate themselves in the Portuguese olive oil market.

The structure of the paper is as follows. In the next section, a description of the data and the methodology used is included. Then, the results of the empirical analysis are shown, followed by their discussion. At the end of the paper, we finish with the conclusions, limitations, implications and future lines of research. 


\section{Methodology}

The conceptual framework of this study draws on work previously undertaken by other researchers, especially that conducted by Sharma and colleagues (Shimp and Sharma, 1987, Sharma et al., 1995, Durvasula et al., 1997). The conceptual framework for the study is presented in Figure 1.

For this paper, a survey was taken of 421 olive oil consumers in Lisbon in August 2015. To design the sample, Lisbon population data from 2012 was used according to the National Census of the National Statistics Institute (2014). Random, stratified sampling (Parasuraman, 1991) was conducted by district, population, gender and age group: between 18 and 24 years old, 25 to 34,35 to 49,50 to 64 , and over 64 years of age. Those surveyed were about to buy food for their home consumption in supermarkets and hypermarkets. The error level was below $4.87 \%$, for a $95.5 \%$ confidence level, under the principle of maximum indetermination, as is seen in the technical details in Table 1.
The definitive questionnaire was divided into four thematic sections: 1) olive oil consumption characteristics, 2) purchasing attitudes, 3) various ethnocentric statements and 4) consumer socioeconomic characteristics.

The Annex presents the 17 items comprising the Consumer Ethnocentric Tendency Scale (CETSCALE) (Bawa, 2004; Kavak and Gumusluoglu, 2007; Chryssochoidis et al., 2007; Brugarolas et al., 2009; Bernabéu et al., 2013) which were included in the survey to identify the ethnocentric attitudes of consumers in Lisbon. Consumers were asked to score each of the variables from 1 to 7 , according to their level of agreement or disagreement with the statement. A score of 1 corresponds to "I totally agree" and 7 corresponds to "I totally disagree". Considering that the total score awarded by each individual to the scale may vary between 17 and 119 , the lowest scores identify the least ethnocentric consumers and the highest scores, the most ethnocentric consumers.

Figure 1 - Conceptual Framework.

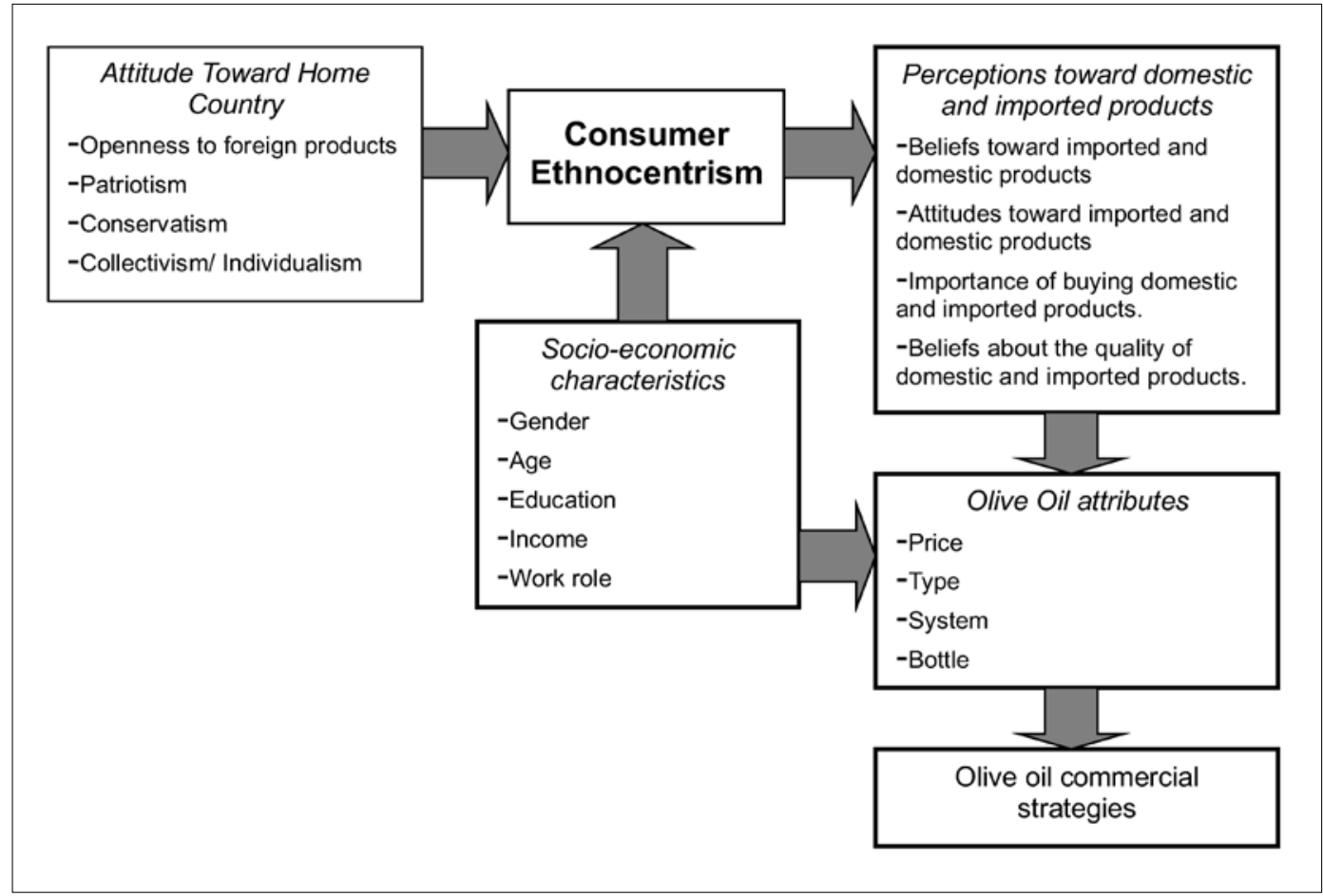


Table 1 - Technical details.

\begin{tabular}{|l|l|}
\hline Ambit & City of Lisbon (Portugal) \\
\hline Universe & Adult olive oil consumers \\
\hline Survey size & 421 surveys \\
\hline Survey error & $\pm 4.87 \%$ \\
\hline Level of confidence & $95.5 \%(\mathrm{k}=2)$ \\
\hline Sampling & $\begin{array}{l}\text { Stratified with proportional affixation by population district, gender } \\
\text { and age }\end{array}$ \\
\hline Control & Of coherence and stability \\
\hline Preliminary questionnaire & Pretest to 25 individuals \\
\hline Field work & August 2015 \\
\hline
\end{tabular}

" $k$ " is a constant that depends on the level of confidence we assign. The confidence level indicates the probability that the results of our investigation are certain.

We then conducted a direct segmentation, taking the mean score as the reference. Thus, consumers with a total score lower than the mean were considered "less ethnocentric", meaning they exhibited a more favourable attitude towards products produced outside their region of origin (Camarena-Gómez and Sanjuán, 2010). Each segment was typified according to socioeconomic characteristics and preferences related to olive oil consumption.

Broadly speaking, there are two types of models used to determine consumer preferences. On one hand, we have consumption models, where respondents give their opinions about different attributes of the same product, and by using aggregation, the total utility is calculated (Wilkie and Pessemier, 1973). On the other hand, we have decomposition models, one of which is the Conjoint Analysis technique (Green and Rao, 1971). In these models, consumers declare their preference for a specific product and the researcher then calculates the importance of each attribute, taking this global preference as the basis (Vázquez, 1990).
In order to determine both the levels for each of the attributes analysed, and the specific attributes used in olive oil studies, we referred to reviews of the literature, interviews with experts and a preliminary questionnaire was prepared. The origin of the olive oil was predetermined as Portuguese, given the importance of this attribute for Portuguese consumers, as the case of Spanish olive oil and Spanish consumers (Espejel and Fandos, 2008; Bernabéu et al., 2009; Erraach et al., 2014; Yangui et al., 2014). Thanks to this prior work, the most important attributes and their levels were selected, specifically: price ( $2.90 € / 1,3.80 € / 1$ and $4.40 € / 1$ ), type (olive oil, virgin olive oil and extra virgin olive oil), ${ }^{1}$ bottle (plastic, glass) and finally, production system (conventional, organic).

The combination of the ten levels of these four attributes yielded 36 different products. This is too many products to show to the consumer. Hence, we utilised an orthogonal design, which allows to reduce the number of options to nine ${ }^{2}$ (Table 2). Thus, eliminating

${ }^{1}$ Extra virgin olive oil is maximum quality oil. It is obtained directly from olives in good condition, through mechanical procedures only, has perfect flavour and aroma, and is free from defects. The degree of its acidity is not over $0.8^{\circ}$, expressed as a percentage of oleic acid. Virgin olive oil follows the same quality parameters as extra virgin olive oil regarding production methods. The difference is that it cannot have more than $2^{\circ}$ of acidity. Such defects should be practically imperceptible to the consumer. Lastly, olive oil is a mixture of olive oil with virgin or virgin extra olive oil. The degree of acidity of this olive oil cannot be over $1^{\circ}$ (IOC, 2013).

2 The number of products evaluated by the consumers was 11. Nine corresponded to the orthogonal design (those used in calculating the utilities). Two additional products (holdout cases) were for verifying the validity of the utility of the first 9 products (which was not significant). Therefore, they were considered valid (Bernabéu et al., 2013). 
Table 2 - Hypothetical olive oil cards shown to those surveyed.

\begin{tabular}{|cclll|}
\hline Card number & Price $(\epsilon / L)$ & \multicolumn{1}{c}{ Type } & \multicolumn{1}{c|}{ Bottle } & \multicolumn{1}{c|}{ System } \\
\hline 1 & 2.90 & Olive oil & Plastic & Conventional \\
2 & 3.80 & Olive oil & Glass & Conventional \\
3 & 3.80 & Virgin olive oil & Glass & Conventional \\
4 & 2.90 & Virgin olive oil & Glass & Organic \\
5 & 4.40 & Virgin olive oil & Plastic & Conventional \\
6 & 4.40 & Extra virgin olive oil & Glass & Conventional \\
7 & 2.90 & Extra virgin olive oil & Glass & Conventional \\
8 & 4.40 & Olive oil & Glass & Organic \\
9 & 3.80 & Extra virgin olive oil & Plastic & Organic \\
\hline
\end{tabular}

the interactions, information is obtained on the main effects. Evidently, reducing the number of options involves a loss of information but this loss is more than compensated for by the advantage of showing only nine products to each respondent (Kirk, 1982; Braña et al., 1995).

Once the hypothetical olive oil cards were designed, they were shown to each of the respondents who assigned a score from 1 to 10 to each card depending on their declared preferences. They had the possibility of repeating scores on more than one card. The number 1 corresponded to the lowest degree of preference and 10 to the highest, according to the complete profile method. The object was to discover which characteristics had a greater influence on the total preference for the olive oil in question, as well as the relative importance of each attribute.

The specification of the conjoint analysis model is based on the hypothesis that respondent preferences, or global olive oil valuation, is obtained from the individual scores for each attribute, so that the sum of those scores generates the global valuation (Steenkamp, 1987). An additive model was used as the starting point, since, in almost every case, it explains a very high percentage, between $80 \%$ and $90 \%$, of the variation in individual preferences. Its formula is shown in the following equation:

$$
\begin{aligned}
\text { Valuation }= & \beta_{0}+\sum_{i=1}^{3} \beta_{i} D_{1 i}+\sum_{j=1}^{3} \beta_{j} D_{2 j}+ \\
& +\sum_{k=1}^{3} \beta_{k} D_{3 k}+\sum_{l=1}^{3} \beta_{l} D_{4 l}
\end{aligned}
$$

where $\beta_{i}, \beta_{j}, \beta_{k}$ and $\beta_{l}$ are the coefficients associated with levels $\mathrm{i}(\mathrm{i}=1,2,3), \mathrm{j}(\mathrm{j}=1,2,3), \mathrm{k}$ $(\mathrm{k}=1,2)$, and $\mathrm{l}(\mathrm{l}=1,2)$ of the attributes of price (1), type (2), bottle (3) and system (4), respectively, and where $D_{l i}, D_{2 j}, D_{3 k}$ and $D_{4 l}$ are the fictitious variables for each attribute, considering the levels of each attribute as categorical.

The final result of the Conjoint program permits estimating the partial utilities of each attribute and the total utility of each profile (Espejel and Fandos, 2008; Menapace et al., 2011; Imani et al., 2013; Erraach et al., 2014; Bernabéu et al., 2016). Using the partial utilities of each respondent to determine consumer preference structure, the relative importance (RI) of the attributes of each of them was calculated, as well as the proportion of the range assigned to each attribute over the total range variation (Halbrendt et al., 1991; Hair et al., 1999).

$$
R I(\%)=\frac{\max U_{i}-\min U_{i}}{\sum\left(\max U_{i}-\min U_{i}\right)} \times 100
$$

where $R I$, is the relative importance, $\max U_{i}$ is the maximum utility and $\min U_{i}$ is the minimum utility.

Socioeconomic characteristics of the sample are shown in Table 3.

\section{Results}

Generally, consumers from Lisbon exhibited a clear ethnocentric behaviour regarding products made in their country, since the values obtained 
Table 3 - Sample socio-economic characteristics of the subjects participating to the consumer panel (\%).

\begin{tabular}{|c|c|c|c|}
\hline \multirow{2}{*}{ Variable/Levels } & & \multicolumn{2}{|c|}{ Lisbon } \\
\hline & & Population $^{a}$ & Sample \\
\hline \multirow{2}{*}{ Gender } & Male & 45.8 & 48.0 \\
\hline & Female & 54.2 & 52.0 \\
\hline \multirow{5}{*}{$\begin{array}{l}\text { Age } \\
\text { (in years) }\end{array}$} & $18-24$ & 8.6 & 13.1 \\
\hline & $25-34$ & 16.9 & 20.0 \\
\hline & $35-49$ & 23.9 & 17.1 \\
\hline & $50-64$ & 22.3 & 17.1 \\
\hline & $\geq 65$ & 28.3 & 32.7 \\
\hline \multirow{3}{*}{ Education } & Grade School & 46.9 & 33.3 \\
\hline & High School & 17.1 & 19.8 \\
\hline & College & 36.0 & 46.9 \\
\hline \multirow{6}{*}{ Work role } & Housewife & 3.2 & 0.2 \\
\hline & Employee & 47.1 & 39.0 \\
\hline & Student & 7.3 & 13.8 \\
\hline & Business person & 9.5 & 7.6 \\
\hline & Retired & 31.4 & 31.9 \\
\hline & Other & 1.5 & 7.5 \\
\hline \multirow{5}{*}{$\begin{array}{l}\text { Monthly family net } \\
\text { income }(€)^{\mathrm{b}}\end{array}$} & $<900$ & 48.0 & 11.9 \\
\hline & 900 to $<1,500$ & 27.5 & 38.4 \\
\hline & 1,500 to $<2,100$ & 10.8 & 28.0 \\
\hline & 2,100 to $<3,000$ & 6.8 & 14.6 \\
\hline & $>3,000$ & 6.9 & 7.1 \\
\hline
\end{tabular}

${ }^{a}$ Source: National Statistics Institute (2014).

${ }^{b}$ Data available is for Portugal.

on the CETSCALE are above the halfway score of the scale. Consumers were then segmented as a function of the sample median, identifying the most and the least ethnocentric consumers in Lisbon city with a maximum level of error of $1 \%$ (Table 4).

An analysis of the socioeconomic characteristics of the consumer segments shows, with significant differences, that the less ethnocentric consumers are those younger, with the highest educational level (frequently with a university degree), employees or business persons, and with a medium or high family income (over $1,500 € /$ month). On the other hand, the more ethnocentric consumers are older and are more frequently women (Table 5).
Regarding the structure of olive oil consumer preferences, according to their degree of ethnocentrism, the attributes most valued by Lisbon consumers when choosing olive oil are: price (62.39\%), followed by type of oil (17.15\%), bottle $(11.92 \%)$ and, finally, production system (8.54\%). Thus, we can state that Lisbon olive oil consumers prefer economic, extra virgin olive oil, sold in a glass bottle and produced organically.

Nonetheless, as suggested by Shimp and Sharma (1987), consumers' ethnocentric tendencies do not function uniformly, with segments of population exhibiting ethnocentric tendencies to differing degrees. In this regard, we have determined the preferences of olive oil consumer depending on their degree of ethnocentrism (Table 6). 
Table 4 - Average values from the CETSCALE variables.

\begin{tabular}{|c|c|c|c|}
\hline \multirow[b]{2}{*}{ Variables } & \multicolumn{3}{|c|}{ Lisbon } \\
\hline & Total & $\begin{array}{c}\text { Seg. 1. More } \\
\text { ethnocentric } \\
50.4 \% \%^{a}\end{array}$ & $\begin{array}{c}\text { Seg. 2. Less } \\
\text { ethnocentric } \\
\quad 49.6 \% \%^{a}\end{array}$ \\
\hline 1. Portugal consumers should always buy products...** & 6.28 & 6.78 & 5.83 \\
\hline $\begin{array}{l}\text { 2. Only those products that are not available in Portugal should be } \\
\text { imported** }\end{array}$ & 4.26 & 5.77 & 2.76 \\
\hline 3. Buying products from Portugal means saving jobs in our region...** & 6.14 & 6.59 & 5.69 \\
\hline $\begin{array}{l}\text { 4. Portugal products should be considered as the first, last and most } \\
\text { important** }\end{array}$ & 5.83 & 6.42 & 5.27 \\
\hline 5. Purchasing products made outside the region is anti-Portugal...** & 4.51 & 5.46 & 3.58 \\
\hline $\begin{array}{l}\text { 6. It is not good to purchase products made outside the region } \\
\text { because...** }\end{array}$ & 5.58 & 6.41 & 4.79 \\
\hline $\begin{array}{l}\text { 7. A true Portugal consumer should always buy products made in } \\
\text { Portugal...** }\end{array}$ & 5.61 & 6.48 & 4.72 \\
\hline $\begin{array}{l}\text { 8. We should purchase products made in Portugal instead of } \\
\text { allowing other...** }\end{array}$ & 6.01 & 6.39 & 5.62 \\
\hline 9. It is best always to purchase products made in Portugal...** & 6.06 & 6.66 & 5.48 \\
\hline 10. There should be very little commerce or acquisition of goods...** & 5.22 & 6.34 & 4.14 \\
\hline $\begin{array}{l}\text { 11. Portugal consumers should not purchase products from other } \\
\text { areas...** }\end{array}$ & 5.71 & 6.52 & 4.92 \\
\hline 12. All imports should be curbed...** & 3.16 & 4.01 & 2.32 \\
\hline $\begin{array}{l}\text { 13. It may cost me more in the long run but I prefer to support } \\
\text { Portugal products** }\end{array}$ & 5.59 & 5.87 & 5.30 \\
\hline $\begin{array}{l}\text { 14. People from other regions should not be authorized to place their } \\
\text { products** }\end{array}$ & 4.33 & 5.84 & 2.84 \\
\hline $\begin{array}{l}\text { 15. Products from other regions should be heavily taxed to reduce } \\
\text { their...** }\end{array}$ & 4.93 & 6.17 & 3.69 \\
\hline 16. We should only purchase from other areas those products that...** & 6.02 & 6.59 & 5.47 \\
\hline $\begin{array}{l}\text { 17. Portugal consumers who purchase products made in other } \\
\text { regions...** }\end{array}$ & 4.70 & 5.91 & 3.49 \\
\hline TOTAL & 89.94 & 104.21 & 75.91 \\
\hline
\end{tabular}

Source: designed by the authors, based on Shimp and Sharma (1987).

${ }^{a}$ Size of the segment.

** Indicates significant differences with a maximum error of $1 \%$.

Thus, we find that consumers in the more ethnocentric segment attach greater importance to the price attribute than consumers in the less ethnocentric segment. In contrast, the less ethnocentric consumers give more importance to attributes such as type of olive oil, type of bottle and production system.
Portuguese producers could focus on the two groups, selling no differentiated oil with low price to the more ethnocentric consumers, and differentiated oil (i.e. organic extra virgin olive oil) for the less ethnocentric consumers. Companies from other countries, such as Spain, should focus on exporting to Portugal mainly high qual- 
Table 5 - Socio-economic characteristics of consumer segments (\%).

\begin{tabular}{|c|c|c|c|}
\hline \multicolumn{2}{|l|}{ Variables } & $\begin{array}{l}\text { Seg. 1. More } \\
\text { ethnocentric }\end{array}$ & $\begin{array}{l}\text { Seg. 2. Less } \\
\text { ethnocentric }\end{array}$ \\
\hline \multirow{2}{*}{ Gender } & Male & 41.5 & 49.7 \\
\hline & Female & 58.5 & 50.3 \\
\hline \multirow{5}{*}{$\begin{array}{l}\text { Age } \\
\text { (in years) }\end{array}$} & $18-24$ & 18.0 & 8.1 \\
\hline & $25-34$ & 15.5 & 26.9 \\
\hline & $35-49$ & 15.5 & 12.7 \\
\hline & $50-64$ & 6.0 & 28.9 \\
\hline & $\geq 65$ & 45.0 & 23.4 \\
\hline \multirow{3}{*}{ Education** } & Grade School & 45.3 & 21.6 \\
\hline & High School & 19.3 & 20.6 \\
\hline & College & 35.4 & 57.7 \\
\hline \multirow{6}{*}{ Work role** } & Housewife & 0.0 & 0.5 \\
\hline & Employee & 30.5 & 45.7 \\
\hline & Student & 17.0 & 10.7 \\
\hline & Business person & 3.0 & 11.2 \\
\hline & Retired & 44.5 & 21.8 \\
\hline & Other & 5.0 & 10.1 \\
\hline \multirow{5}{*}{$\begin{array}{l}\text { Monthly family } \\
\text { net income** }\end{array}$} & $<900 €$ & 13.6 & 10.0 \\
\hline & $900 €$ to $<1,500 €$ & 48.0 & 29.5 \\
\hline & $1,500 €$ to $<2,100 €$ & 25.3 & 30.5 \\
\hline & $2,100 €$ to $<3,000 €$ & 11.1 & 17.9 \\
\hline & $>3,000 €$ & 2.0 & 12.1 \\
\hline
\end{tabular}

** Indicates significant differences with a maximum error of $1 \%$.

ity differentiated oil. Given that the more ethnocentric consumers choose a product depending on its price and the less ethnocentric consumers also value other attributes, it seems logical for marketing strategies promoting olive oil to target the latter consumer group.

\section{Discussion}

It is generally thought that ethnocentric tendencies are especially important in consumers who feel their socioeconomic variables and quality of life are threatened by the competition of foreign products (Shimp and Sharma, 1987). In this regard, Sharma, Shimp and Shin (1995) and Marín (2005) suggest that women tend to be more ethnocentric than men and that consumers with lower educational levels and lower incomes also exhibit greater ethnocentric tendencies. Camarena-Gómez and Sanjuán (2010) identify the most ethnocentric consumers as those with an income of less than $1,500 € /$ month.

The present study confirms that consumers with lower levels of education and lower incomes (1.500 €/month) are more ethnocentrically oriented, but results for gender and age are inconclusive. However, women and older consumers exhibit a more ethnocentric tendency, which is similar to the findings of Bernabéu et al. (2013). Furthermore, our results show significant differences according to consumers' type of employment, which is possibly related to income and educational levels.

With regard to scores on the CETSCALE, in comparison to the results of the study by Bernabéu et al. (2013), conducted in Madrid and 
Table 6 - Utilities assigned to attribute levels.

\begin{tabular}{|c|c|c|c|c|}
\hline \multirow{2}{*}{ Attributes and levels } & \multicolumn{2}{|c|}{ Seg. 1. More ethnocentric } & \multicolumn{2}{|c|}{ Seg. 2. Less ethnocentric } \\
\hline & $R I(\%)$ & $U$ & $R I(\%)$ & $U$ \\
\hline Price** & 65.64 & & 59.09 & \\
\hline $2.90 € / / * *$ & & 2.86 & & 2.53 \\
\hline $3.80 € / l$ & & 0.13 & & 0.05 \\
\hline $4.40 € / l^{* *}$ & & -2.99 & & -2.58 \\
\hline Type* & 15.59 & & 18.73 & \\
\hline Olive Oil* & & -0.38 & & -0.57 \\
\hline Virgin Olive Oil & & -0.02 & & -0.03 \\
\hline Extra Virgin Olive Oil* & & 0.40 & & 0.60 \\
\hline Bottle & 11.11 & & 12.75 & \\
\hline Glass & & 0.43 & & 0.40 \\
\hline Plastic & & -0.43 & & -0.40 \\
\hline System* & 7.66 & & 9.43 & \\
\hline Conventional* & & -0.40 & & -0.10 \\
\hline Organic* & & 0.40 & & 0.10 \\
\hline
\end{tabular}

$R I=$ Relative Importance; $U=$ Utility.

** and * correspond to $1 \%$ and $5 \%$ maximum error levels, respectively.

Barcelona, it is worth noting that average scores in both Madrid (39.49) and Barcelona (44.27) were low, in contrast to the findings for Lisbon (89.94). This is arguably because Lisbon continues to be a medium-sized city, and thus inhabitants have a higher perceived risk of the globalisation of markets, associating the process with the recent economic crisis.

The difference in this perception between Portugal and Spain is especially striking since the two societies are generally thought to be very similar. An analysis of the socioeconomic characteristics of the more ethnocentric consumer segments in both Madrid and Lisbon shows that consumers with the lowest levels of family income are significantly the most ethnocentric (Bernabéu et al., 2013), while the segmentation of consumers in Lisbon shows that individuals with a lower educational level are the most ethnocentric.

However, other similar studies conducted in Spain have yielded higher scores. Brugarolas et al. (2009) obtained 65.29 in the Valencian Community, and Marín (2005) obtained 70.87 in the Province of Valencia. These higher scores might be because the studies included small and large towns, whereas the study conducted by Bernabéu et al. (2013) focused on the two most populated cities in Spain. The size of the town in which the study is conducted might, thus, determine the results obtained.

Studies conducted in other countries reveal a greater tendency towards non-ethnocentrism: Shimp and Sharma (1987) obtained scores ranging from 56.62 and 68.58 in consumers in the United States; Good and Huddleston (1995), found scores of 51.68 for Russian consumers and 69.2 for Polish consumers; Bigné (1999) obtained a score of 52.8 for German consumers, 53.1 for British consumers and 62.3 for those in France. Sharma, Shimp and Shin (1995) obtained a score of 85.07 for South Korean consumers, possibly because the study coincided with the onset of the market globalisation process.

Regarding preferences for olive oil, in the case of Spanish consumers, Espejel and Fandos (2008) found the most important attributes to be colour, taste, form and appearance, while they found origin to be irrelevant. Bernabéu et al. (2009) showed that the most valued attrib- 
utes were type (extra virgin), followed by origin, price and production system (organic). Erraach et al. (2014) reported the most valued attribute to be price, followed by origin, bottle and colour, and, finally, Yangui et al. (2014) demonstrated that the most appreciated attributes were price, origin, protected denomination of origin and brand. In a later work not including the origin attribute, Bernabéu et al. (2016), found that the main attributes were price, followed by type of olive oil, production system and, finally, type of bottle. Regarding the bottle material, Sanz-Cañada et al. (2015) found that the use of glass bottles generated a higher price in the different commercial phases of the chain.

If we compare our results with those of similar studies conducted in other countries, we see that for Italian, French and Canadian consumers the most valued attribute is origin (Caporale et al., 2005; Dekhili et al., (2011); Menapace et al., 2011). In the case of Greek consumers, Krystallis and Ness (2005) also found that the most valued attributes were origin and organic production, with price and bottled being the least valued. Results on the importance of origin among Tunisian consumers vary according to the study consulted (Dekhili et al., 2011; Mtimet et al., 2011).

Ward et al. (2003) also found that for German consumers the most appreciated attribute is origin, which, in turn, determined the evaluation of the other attributes of the olive oil. In contrast, English consumers, according to García et al. (2002), most value the type attribute, followed by price. In a more recent study, Kavallari et al. (2009) found a preference among German and English consumers for bulk rather than packaged olive oil.

Coinciding with the aforementioned authors, we find there is no main attribute in consumer preferences. In some cases the preferred attribute is found to be the type of olive oil, if possible extra virgin (Bernabéu et al., 2009; García et al., 2002; Mtimet et al., 2011), while in other cases it is the origin (Caporale et al., 2005; Menapace et al., 2011; Sottomayor et al., 2010; Ward et al., 2003) and in others, the price (Bernabéu et al., 2016; Erraach et al., 2014; Yangui et al., 2014).
Finally, it is worth noting that, in line with other studies, Portuguese olive oil consumers consider that plastic is associated with a lower quality product, and the opposite is true for materials like glass (Bernabéu et al., 2016; Cabrera et al., 2015; Romo et al., 2013). Furthermore, organic production labels emerge in the case of Portuguese consumers as an additional sign of quality that generates greater utility in olive oil consumers on accordance with results in similar countries (Bernabéu et al., 2016).

\section{Conclusions}

Generally, Lisbon consumers show strong ethnocentric tendencies. This must be taken into account for local producers and for companies exporting to the country. Low education and low income have been traditionally linked to stronger ethnocentric tendencies. In the case of Portugal, the most ethnocentric consumers are mainly older women, with a lower educational level, and also with lower incomes. This is presumably the profile of a Portuguese consumer who perceives more risk in the process of increased globalisation.

Due to the results, the strategies to follow in the case foreign companies exporting olive oil of Lisbon, should vary according to the target population segment. The more ethnocentric consumers attach greater importance to price when purchasing olive oil. Foreign companies, therefore, will only be able to access to this segment if they can offer a significantly more economic olive oil than any nationally produced Portuguese oil.

In contrast, exists a less ethnocentric segment, which is willing to purchase olive oil at a higher price when it is clearly differentiated by type of oil (extra virgin), bottle (glass) and production system (organic). Thus, it seems recommendable for companies exporting olive oil to Portugal to focus their business strategy on product differentiation in order to access the less ethnocentric consumer segment.

Moreover, further effort of Public Administrations to disclose the benefits of extra virgin olive oil or organic olive oil (certified organic production) should be done as an important segment of 
consumers (the more etnocentric) are not giving enough importance to these key attributes.

As regards the limitations of this work, it should be noted that the work was conducted exclusively in Lisbon, a cosmopolitan, city which sets trends and breeds new opinions, while also being a major market for olive oil consumption. It would be advisable to extend the study to other parts of Portugal in order to establish comparisons, since other cities may have stronger ethnocentric tendencies.

Another limitation of the study is that it is based on a survey conducted at one specific moment in time. It would be interesting to analyse the evolution of consumers' ethnocentric behaviour over time, and, in particular, the preferences of olive oil consumers.

\section{References}

Alarcón de la Lastra C., Barranco M.D., Motilva V., Herrerías J.M., 2001. Mediterranean diet and health. Biological importance of olive oil. Current Pharmaceutical Design, 7: 933-950.

Bawa A., 2004. Consumer ethnocentrism, CETSCALE validation and measurement of extent. Vikalpa, 29: 43-57.

Bernabéu R., Díaz M., 2016. Preference for olive oil consumption in the Spanish local market. Spanish Journal of Agricultural Research, 14(4), e0108.

Bernabéu R., Olmeda M., Díaz M., Olivas R., 2009. Oportunidades comerciales para el aceite de oliva de Castilla-La Mancha. Grasas y Aceites, 60: 527535.

Bernabéu R., Prieto A., Díaz M., 2013. Preference patterns for wine consumption in Spain depending on the degree of consumer ethnocentrism. Food Quality and Preference, 28: 77-84.

Bigné E., 1999. Operacionalización del etnocentrismo del consumidor. Presented at VIII Taller de ACEDE, Asociación Científica de Economía y Dirección de la Empresa, Barcelona.

Bilkey W., Nes E., 1982. Country of origin effects on consumer evaluations. Journal of International Business Studies, 13: 89-99.

Braña T., Ferraces M.J., Varela J., 1995. Diseño factorial incompleto. IV Simposium de Metodología de las Ciencias del Comportamiento. Universidad de Murcia.

Brugarolas M., Martínez-Poveda A., Martínez-Carrasco L., 2009. Aceptación de productos en los mercados locales. El aceite de oliva en la Comunidad Valenciana. Presented at VII Congreso de Economía Agraria, Almería, España, 16-18 Sept.

Cabrera E.R., Arriaza M., Rodríguez-Entrena M., 2015. Is the extra virgin olive oil market facing a process of differentiation? A hedonic approach to disentangle the effect of quality attributes. Grasas $y$ Aceites, 66: e105.

Camarena-Gómez D., Sanjuán A.I., 2010. Preferencias hacia el origen de un alimento étnico y la influencia de variables psicográficas. Economía Agraria y Recursos naturales, 10: 71-99.

Caporale G., Policastro S., Carlucci A., Monteleone E., 2005. Consumer expectations for sensory properties in virgin olive oils. Food Quality and Preference, 17: 116-125.

Chasin J., Holzmuller H., Jaffe E., 1988. Stereotyping, buyer familiarity and ethnocentrism, a cross-cultural analysis. Journal of International Consumer Marketing, 1: 9-29.

Chin K-Y., Ima-Nirwana S., 2016. Olives and bone, A green osteoporosis prevention option. International Journal of Environmental Research and Public Health, 13(8): 755.

Chryssochoidis G., Krystallis A., Perreas P., 2007. Ethnocentric beliefs and country-of-origin $\mathrm{COO}$ effect, Impact of country, product and product attributes on Greek consumers' evaluation of food products. European Journal of Marketing, 41: 1518-1544.

COMTRADE, 2015. UN Comtrade database. United Nations. Consulted: 01/07/2019.

Dekhili S., Sirieix L., Cohen E., 2011. How consumers choose olive oil: The importance of origin cues. Food Quality and Preference, 22: 757-762.

Del Río L.F., Gutiérrez-Casado E., Varela-López A., Villalba J.M., 2016. Olive oil and the hallmarks of aging. Molecules, 21(2): 163.

Durvasula S., Andrews C., Netemeyer R., 1997. A cross-cultural comparison of consumer ethnocentrism in the United States and Russian. Journal of International Consumer Marketing, 9: 73-84.

Erraach Y., Sayadi S., Gómez A.C., Parra-López C., 2014. Consumer-stated preferences towards Protected Designation of Origin PDO labels in a traditional olive oil producing country. The case of Spain. New Medit, 13: 11-19.

Espejel J., Fandos C., 2008. La calidad percibida como antecedente de la intención de compra de aceite de oliva del Bajo Aragón con denominación de origen protegida. Esic Market, 131: 231-275.

Esposito K., Maiorino M.I., Bellastella G., Panagiotakos D.B., Giugliano D., 2017. Mediterranean 
diet for type 2 diabetes, cardiometabolic benefits. Endocrine, 56: 27-32.

García M., Aragonés Z., Poole N., 2002. A repositioning strategy for olive oil in the UK market. Agribusiness, 18: 163-180.

Good L.K., Huddleston P., 1995. Ethnocentrism of Polish and Russian consumers. Are feelings and intentions related? International Marketing Review, 12: 35-48.

Green P.E., Rao V.R., 1971. Conjoint Measurement from Quantifying Judgemental Data. Journal of Marketing Research, 8: 355-363.

Hair J.F., Anderson R.E., Tatham R.L., Black W.C., 1999. Análisis multivariante. Madrid: Prentice-Hall Iberia.

Halbrendt C.K., Wirth E.F., Vaughn G.F., 1991. Conjoint analysis of the Mid-Atlantic food-fish market for farm-raised hybrid striped bass. Southern Journal of Agricultural Economics, July: 155-163.

Han C., 1988. The role of consumer patriotism in the choice of domestic versus foreign products. Journal of Advertising Research, June-July: 25-32.

Hernáez A., Farràs M., Fitó M., 2016. Olive oil phenolic compounds and high-density lipoprotein function. Current Opinion in Lipidology, 27: 47-53.

Hung C., 1989. A country of origin product image study, the Canadian perception and nationality biases. Journal of International Consumer Marketing, 1: 5-26.

Imami D., Zhllima E., Canavari M., Merkaj E., 2013. Segmenting Albanian consumers according to olive oil quality perception and purchasing habits. Agricultural Economics Review, 14: 97-112.

International Olive Council IOC, 2013. Glossary. Madrid: International Olive Council. https://www. internationaloliveoil.org/tools-and-links/glossary/?lang=en_US. Accessed 8/12/2016.

International Olive Council IOC, 2015. Trends in world olive oil consumption. https://www.oliveoilmarket.eu/trends-in-world-olive-oil-consumptionioc-report/ Accessed 8/12/2016.

Johansson J.K., Douglas S.P., Nonaka I., 1985. Assessing the impact of country of origin on product evaluations, a new methodological perspective. Journal of Marketing Research, 22: 388-396.

Kavak B., Gumusluoglu L., 2007. Segmenting food markets. The role of ethnocentrism and lifestyle in understanding purchasing intentions. International Journal of Market Research, 49: 71-94.

Kavallari A., Maas S., Schmitz M., 2009. Evolution of olive oil import demand structures in nonproducing countries: the cases of Germany and the UK. Presented at 113th EAAE Seminar, A resilient Euro- pean food industry and food chain in a challenging world, Chania, Greece.

Kaynak E., Kara A., 1996. Consumer ethnocentrism in an emerging economy of Central Asia. In: Summer Educators' Conference Proceedings. San Diego, CA: American Marketing Association, 514-520.

Kirk J., 1982. Experimental design: Procedures for the behavioural sciences (2nd ed.). Monterrey, CA: Brooks-Cole Co.

Krystallis A., Ness M., 2005. Consumer preferences for quality foods from a South European perspective: A conjoint analysis implementation Greek olive oil. The International Food and Agribusiness Management Review, 8: 62-91.

Marín S.C., 2005. El origen doméstico de los productos como ventaja competitiva: la etnocentricidad del consumidor. Valencia: Universidad de Valencia.

Menapace L., Colson G., Grebitus C., Facendola M., 2011. Consumers' preferences for geographical origin labels, evidence from the Canadian olive oil market. European Review of Agricultural Economics, January: 1-20.

Mtimet N., Ujiie K., Kashiwagi K., Zaibet L., Nagak M., 2011. The effects of information and country of origin on Japanese olive oil consumer selection. Presented at the EAAE 2011 Congress, Change and Uncertainty. Challenges for Agriculture, Food and Natural Resources, Zurich, Switzerland.

Ostrowska E., Gabler N.K., Ridley D., Suster D., Eagling D.R., Dunshea F.R., 2006. Extra-virgin and refined olive oils decrease plasma triglyceride, moderately affect lipoprotein oxidation susceptibility and increase bone density in growing pigs. Journal of the Science of Food and Agriculture, 86: 1955-1963.

Parasuraman A., 1991. Marketing Research (2nd ed.). Reading: Addison-Wesley.

Ramos C.I., Andrade de Lima A.F., Grilli D.G., Cuppari L., 2015. The Short-Term Effects of Olive Oil and Flaxseed Oil for the Treatment of Constipation in Hemodialysis Patients. Journal of Renal Nutrition, 25: 50-56.

Romo R., Lagos M., Gil J.M., 2013. Estudio de los atributos que inciden en el precio del aceite de oliva en Chile utilizando una función hedónica. Presented at IX AEEA Congress, Castelldefels, España.

Sanz-Cañada J., Barneo-Alcántara M., García-Brenes M.D., 2015. Value Chain and Typicity Analysis in Jaén Mountain Olive Oil, Spain. New Medit, 14: 50-60.

Sharma S., Shimp T., Shin J., 1995. Consumer Ethnocentrism, A test of antecedents and moderators. Journal of the Academy of Marketing Science, 23: 26-37. 
Shimp T., Sharma S., 1987. Consumer Ethnocentrism, Construction and Validation of the CETSCALE. Journal of Marketing Research, 24: 280-289.

Sikand G., Kris-Etherton P., Boulos N.M., 2015. Impact of Functional Foods on Prevention of Cardiovascular Disease and Diabetes. Current Cardiology Reports, 17: 16.

Sottomayor M., Monteiro S.D.M., Teixeira M.S., 2010. Valuing nested names in the Portuguese olive oil market. An exploratory study. Presented at $116^{\text {th }}$ EAAE Seminar, Parma, Italy.

Steenkamp J.B., 1987. Conjoint measurement in ham quality evaluation. Journal of Agricultural Economics, 38: 473-480.

Supphellen M., Gronhaug K., 2003. Building foreign brand personalities in Russia, the moderating effect of consumer ethnocentrism. International Journal of Advertising, 22: 203-226.

Vázquez R., 1990. Investigación de las preferencias del consumidor mediante "análisis conjunto" importancia para el Diseño de nuevos productos. Información Comercial Española, July: 149-163.

Wall P., Heslop L.A., 1986. Consumer attitudes to- ward Canadian-made versus imported product. Journal of the Academy of Marketing Science, 8: 345-356.

Ward R., Briz J., De Felipe I., 2003. Competing supplies of olive oil in the German market: An application of multinomial logit models. Agribusiness, 19: 393-406.

White P., 1979. Attitudes of U.S. purchasing managers toward industrial products manufactured in selected Western European nations. Journal of International Business Studies, 10: 81-90.

Wilkie W.L., Pessemier E.A., 1973. Issues in Marketing's Use of Multi-attribute Attitude Models. Journal of Marketing Research, 10: 428-441.

Witkowsky T., 1998. Consumer ethnocentrism in two emergent markets, determinants and predictive validity. Advances in Consumer Research, 25: 258263.

Yangui A., Costa-Font M., Gi J.M., 2014. Revealing additional preference heterogeneity with an extended random parameter logit model: the case of extra virgin olive oil. Spanish Journal of Agricultural Research, 12: 553-567. 


\section{Appendix 1}

Consumer Ethnocentric Tendency Scale (CETSCALE)

Items

1. [1] consumers should always buy products from the region rather those from other places.

2. Only those products that are not available in [1] should be imported.

3. Buying products from [1] means saving jobs in our region.

4. [1] products should be considered as the first, last and most important.

5. Purchasing products made outside the region is anti-[1].

6. It is not good to purchase products made outside the region because it leaves people from [1] without work.

7. A true [1] consumer should always buy products made in [1].

8. We should purchase products made in [1] instead of allowing other regions to get rich at our expense.

9. It is best always to purchase products made in [1].

10. There should be very little commerce or acquisition of goods from other regions unless it is necessary.

11. [1] consumers should not purchase products from other areas, as it harms [1] businesses and causes unemployment.

12. All imports should be curbed.

13. It may cost me more in the long run but I prefer to support [1] products.

14. People from other regions should not be authorized to place their products on our markets.

15. Products from other regions should be heavily taxed to reduce their entry into [1].

16. We should only purchase from other areas those products that we cannot obtain in our own region.

17. [1] consumers who purchase products made in other regions are responsible for placing their fellow citizens on unemployment.

Source: Our own elaboration based on Shimp and Sharma (1987).

[1] Portugal. 